\title{
Penerapan Metode Vikor dalam Seleksi Penerimaan Bonus Pada Salesman Indihome
}

\author{
Yogi Primadasa ${ }^{1}$, Hengki Juliansa ${ }^{2}$ \\ ${ }^{1,2}$ Sistem Informasi STMIK Bina Nusantara Jaya Lubuklinggau \\ Jl. Yos Sudarso, Lubuk Linggau Timur. II, Kota Lubuklinggau, Sumatera Selatan 31613 \\ E-mail : hengki.juliansa@gmail.com¹,yogiak45@gmail.com²
}

\begin{abstract}
Abstrak
Indihome merupakan salah satu produk dari PT.Telkom Indonesia yang berdedikasi untuk layanan akses internet bagi rumah tangga serta bisnis skala kecil dan menengah Pada PT.Telkom wilayah Lubuklinggau. PT.Telkom dalam menetapkan karyawan yang mendapakan bonus hanya menghitung dari banyaknya target pencapaian salesman tersebut, yang mana peneliti anggap kriteria tersebut kurang efisien dalam pengambilan keputusan. Untuk mendukung efisiensi dalam menentukan kriteria, peneliti melakukan quisioner dalam menentukan kriteria yang akan di gunakan dalam pengambilan keputusan . Hasil dari kuisioner dengan melakukan uji validitas didapatkan 4 kriteria yang valid yaitu, Absensi, Pencapaian Target, Kerja Sama Tim dan Perilaku. Sistem pendukung keputusan untuk pemberian bonus adalah sebuah alternatif untuk membantu pengambilan keputusan dalam proses pemberian bonus untuk salesman tiap periodenya. Untuk membantu pengambilan keputusan dalam proses pemberian bonus maka dibutuhkan sistem pendukung keputusan untuk perangkingan seleksi, salah satu metode yang digunakan untuk sistem pendukung keputusan adalah metode VIKOR. Hasil yang didapatkan menggunakan metode Vikor ini adalah berupa perangkingan, Perangkingan pertama didapatkan oleh salesman bernama Sugiono dengan hasil Qi $=0$
\end{abstract}

Kata Kunci : Sistem Pendukung Keputusan, Seleksi, Bonus, Vikor

\begin{abstract}
Indihome is one of the products from PT Telkom Indonesia that is dedicated to internet access services for households and small and medium scale businesses at PT. Telkom Lubuklinggau region. PT.Telkom in determining employees who get bonuses only counts from the number of achievement targets of the salaesman, which researchers consider these criteria to be less efficient in decision making. To support efficiency in determining criteria, researchers conduct a questionnaire in determining the criteria that will be used in decision making. The results of the questionnaire by testing the validity obtained 4 valid criteria, namely, Attendance, Achievement of Targets, Teamwork and Behavior. Decision support system for giving bonuses is an alternative to assist decision making in the process of giving bonuses to salesmen each period. To help make decisions in the bonus process, a decision support system is needed for ranking selection, one of the methods used for decision support systems is the VIKOR method. The results obtained using this Vikor method are in the form of ranking, the first ranking obtained by salaesman named Sugiono with the result $Q i=0$.
\end{abstract}

Keywords : Decision support system, selection, Bonus, Vikor

\section{Pendahuluan}

Setiap perusahaan, instansi, organisasi atau badan usaha mempunyai kewajiban akan memberikan gaji sebagai kompensasi dari kerja seorang karyawan, selain pemberian gaji pokok pada karyawannya, beberapa perusahaan / instansi seringkali juga memberikan bonus untuk memacu kinerja dan produktifitas kerja karyawannya. Seorang karyawan yang menerima bonus tersebut harus memenuhi beberapa kriteria tertentu yang berhubungan dengan kinerja, produktifitas, kedisiplinan, dan prestasi sesuai yang ditentukan oleh masing-masing instansi atau perusahaan. Bonus dapat berbentuk uang maupun barang sesuai dengan kebijakan masingmasing perusahaan. Penentuan kriteria pada masing-masing perusahaan sangat diperlukan untuk 
mendukung dalam pemberian bonus. Sebagai contoh kriteria-kriterianya adalah absen, pencapaian target, kerjasama tim, dan perilaku[1].

Indihome merupakan salah satu produk unggulan dari PT.Telkom Indonesia yang berdedikasi untuk layanan akses internet bagi rumah tangga serta bisnis skala kecil dan menengah Pada PT.Telkom wilayah Lubuklinggau. PT.Telkom dalam menetapkan karyawan yang mendapakan bonus hanya menghitung dari banyaknya target pencapaian salaesman tersebut, yang mana peneliti anggap kriteria tersebut kurang efisien dalam pengambilan keputusan. Untuk mendukung efisiensi dalam menentukan kriteria, peneliti melakukan quisioner dalam menentukan kriteria yang akan di gunakan dalam pengambilan keputusan. Selain itu, dalam pemberian penilaian kriteria tidak hanya terpaku pada rata-rata nilai dari kriteria yang menjadi prioritas, sehingga karyawan mempunyai nilai bukan hanya dari satu prioritas saja. Pengambilan keputusan yang tidak tepat akan mengakibatkan karyawan yang terpilih terkadang tidak sesuai dengan kenyataan yang sebenarnya, sedangkan karyawan yang kinerjanya bagus terkadang tidak terpilih.

Sistem pendukung keputusan untuk pemberian bonus adalah sebuah alternatif untuk membantu pengambilan keputusan dalam proses pemberian bonus untuk salesman tiap periodenya. Sistem yang dirancang untuk menghasilkan informasi yang dapat membantu pihak personalia untuk menilai kinerja karyawan dan sebagai alat bantu dalam menentukan pemberian bonus yaitu dengan menggunakan data untuk memecahkan masalah. Sistem pendukung keputusan merupakan sistem informasi interaktif yang menyediakan informasi, pemodelan, dan pemanipulasian data. Sistem ini digunakan untuk membantu di dalam proses pengambilan keputusan dalam situasi yang semiterstruktur dan situasi yang tidak terstruktur, dimana tidak seorangpun tahu secara tidak pasti bagaimana keputusan seharusnya dibuat. Sistem pendukung keputusan biasanya dibangun untuk mendukung solusi atas suatu masalah atau untuk mengevaluasi suatu peluang[2]

Untuk membantu pengambilan keputusan dalam proses pemberian bonus maka dibutuhkan sistem pendukung keputusan untuk perangkingan seleksi, Sistem pendukung keputusan ini dibantu dengan menggunakan metode Vikor. Metode VIKOR merupakan salah satu metode yang berfokus pada perangkingan setiap seleksi dari sebuah alternatif. Metode Vikor juga membantu mengatasi permasalahan multikriteria pada system yang kompleks. selain itu juga metode Vikor ini memiliki kelebihan dalam kompromi alternatif yang mampu menyelesaikan rekomendasi dari kasus multi kriteria dalam penentuan pemberian bonus pada salesman[3]

Pada penelitian sebelumnya metode Vikor mampu menentukan penerima beasiswa berdasarkan banyaknya kriteria dengan melakukan proses seleksi dan perangkingan[3]. Pada Nilai V metode Vikor sangat berpengaruh pada hasil perangkingan terutama pada hasil yang memiliki peringkat pertama yang akan digunakan sebagai acuan untuk mengambil keputusan[4].

Sistem Pendukung Keputusan dapat membantu proses seleksi calon karyawan menggunakan metode Promethee. Sistem ini mampu mengambil keputusan dalam melakukan seleksi calon karyawan[5].

Dari refrensi diatas sistem pendukung keputusan seleksi menggunakan metode Vikor ini mampu memberikan solusi terhadap seleksi pemberian bonus salesman Indihome.

\section{Metodologi Penelitian}

\subsection{Kerangka Berfikir}

Kerangka berpikir mengidentifikasi berbagai faktor sebagai masalah-masalah yang penting [6]. Gambar Kerangka berfikir dapat dilihat dibawah ini :

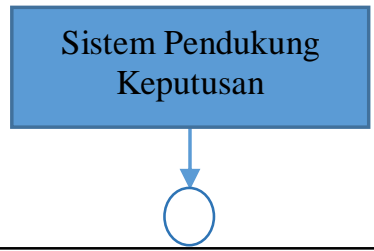




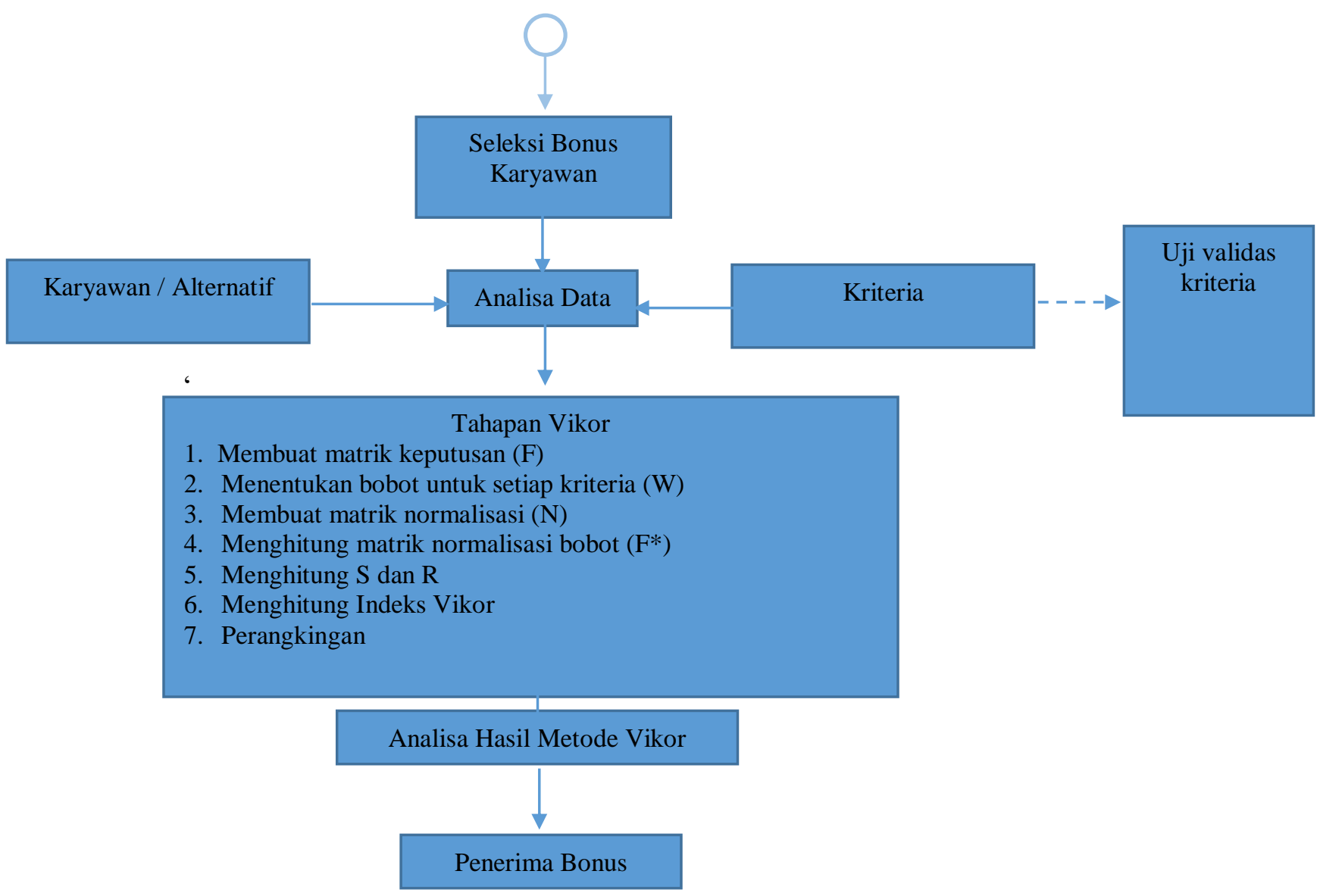

\section{Gambar 1. Kerangka Berfikir}

\subsection{Sistem Pendukung Keputusan}

Sistem pendukung keputusan merupakan salah satu alternatif yang dapat digunakan dalam membantu proeses pengambilan keputusan dalam situasi semi terstruktur dan tidak terstruktur supaya lebih efektif dengan menggunakan data dan model yang tersedia.[7][8][9]. Sistem pendukung keputusan merupakan resources individu secara intelek dengan kemampuan komputer guna meningkatkan kualitasi keputusan dan bisa sebagai manajemen pengambilan keputusan[10].

\subsection{Metode Vikor ( Vise Kriterijumska Optimizajica I Kompromiso Resenje)}

Vikor merupakan metode multi criteria decision making dari sistem pendukung keputusan yang dapat menyekeksi dari satu kriteria[11]. Penggunaan Vikor untuk peringkasan otomatis yang dilakukan dengan cara mensimulasikan suatu kasus untuk diproses, untuk menghasilakan urutan peringkat berdasarkan perangkingan alternatif[2][12]. Berikut langkah kerja dari metode Vikor[2][3][10][11] :

a. Membuat matrik keputusan alternatif dan kriteria $(\mathrm{F})$ dengan persamaan dibawah ini :

$$
F=\begin{array}{r}
A_{1} \\
A_{2} \\
\vdots \\
\vdots \\
A_{m}
\end{array}\left[\begin{array}{cccc}
C_{x 1} & C_{x 2} & \mathrm{~mm} & C_{x n} \\
x_{11} & x_{12} & \mathrm{~mm} & x_{1 n} \\
x_{21} & x_{22} & \mathrm{~mm} & x_{2 n} \\
\vdots & \vdots & \vdots & \vdots \\
x_{m 1} & x_{m 2} & \mathrm{~mm} & x_{m n}
\end{array}\right]
$$

Dimana $\mathrm{F}$ sebagai matrik keputusan, $\mathrm{A}_{1}$ alternatif ke $-i, i=1,2,3 \ldots \mathrm{m}$ adalah nomor urutan alternatif dan $\mathrm{C}_{\mathrm{j}}$ kriteria ke- $j, j=1,2,3 . . \mathrm{m}$ adalah nomor urutan kriteria, serta $\mathrm{X}_{\mathrm{ij}}$ merupakan respon alterntif pada kriteria. 
b. Menentukan bobot untuk setiap kriteria (W) dengan persamaan di bawah ini :

$$
W=\Sigma_{j}^{n}={ }_{1} W_{j}=1
$$

Dimana $\mathrm{W}_{\mathrm{j}}$ merupakan bobot kriteria dan $\mathrm{j}=1,2,3$ merupakan nomor urutan kriteria

c. Membuat matrik normalisasi $(\mathrm{N})$ dengan menentukan nilai maximum dan minumum untuk mendapatkan solusi ideal dari setiap kriteria. $\mathrm{N}$ dengan persamaan di bawah ini :

$$
N_{i j}=\frac{\left(f_{j}^{+}-f_{i j}\right)}{\left(f_{j}^{+}-f_{j}^{-}\right)}
$$

Dimana $f_{i j}$ merupakan respon alternatif pada kriteria, $\mathrm{f}^{+}{ }_{\mathrm{j}}$ merupakan nilai maximum dalam satu kriteria, $\mathrm{f}_{\mathrm{j}}$ merupakan nilai minumum dalam satu kriteria.

d. Menghitung matrik normalisasi Bobot $\left(\mathrm{F}^{*}\right)$

Normalisasi bobot ini dilakukan dengan cara melakukan perkalian bobot kriteria (W) dengan nilai data yang sudah di normalisasi $(\mathrm{N})$, persamaannya sebagai berikut :

$$
F_{i j}^{*}=W_{j} \cdot N_{i j}
$$

Dimana $F^{*}{ }_{i j}$ merupakan hasil normalisasi bobot dari alternatif dan kriteria, $\mathrm{W}_{\mathrm{j}}$ nilai bobot dari kriteria dan $\mathrm{N}_{\mathrm{ij}}$ nilai data ternomalisasi dari alternatif dan kriteria.

e. Menghitung utility measure (S) dan regret measure (R) dari setiap alternatif, dengan persamaan di bawah ini :

$$
\begin{aligned}
& S_{i}=\sum_{j}^{n}={ }_{1} W_{j} \frac{\left(f_{j}^{+}-f_{i j}\right)}{\left(f_{j}^{+}-f_{j}^{+}\right)} \\
& R_{\mathrm{i}}=\operatorname{maxj}\left[\frac{\left(f_{j}^{+}-f_{i j}\right)}{\left(f_{j}^{+}-f_{j}^{-}\right)}\right]
\end{aligned}
$$

Dimana $\mathrm{S}_{\mathrm{i}}$ merupakan maximum group utility dan $\mathrm{R}_{\mathrm{i}}$ merupakan minimum individual regret yang mana keduanya merupakan utility measure yang di ambil dari titik terjauh dan terdekat sebagai solusi ideal.

f. Menghitung Indeks VIKOR dengan persamaan berikut :

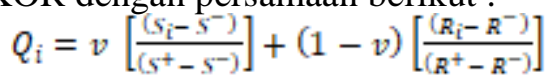

Dimana $\mathrm{S}-=\min \mathrm{Si}, \mathrm{S}+=\max \mathrm{Si}$, dan $\mathrm{R}-=\min \mathrm{Ri}, \mathrm{R}+=\max \mathrm{Ri}$ dan $\mathrm{V}=0,5$. Nilai Qi terkecil / terendah merupakan hasil yang terbaik.

g. Melakukan solusi kompromi dengan 2 kondisi, kondisi pertama yaitu Acceptable Advante menggunakan persamaan di bawah ini :

$$
\begin{gathered}
Q\left(A_{2}\right)-Q\left(A_{1}\right) \geq D Q \\
D Q=\frac{1}{(m-1)}
\end{gathered}
$$

Dimana $A_{2}$ merupakan alternatif urutan ke dua pada perangkingan $\mathrm{Q}$ dan $\mathrm{A}_{1}$ merupakan

\begin{tabular}{|c|c|c|c|c|c|c|c|c|c|c|c|}
\hline \multirow{2}{*}{ Koresponden } & \multicolumn{11}{|c|}{ Kriteria } \\
\hline & K1 & $\mathrm{K} 2$ & K3 & K4 & K5 & K6 & K7 & K8 & K9 & K10 & K11 \\
\hline 1 & 4 & 5 & 4 & 4 & 5 & 5 & 5 & 3 & 4 & 4 & 5 \\
\hline 2 & 4 & 5 & 4 & 4 & 5 & 4 & 3 & 3 & 5 & 5 & 3 \\
\hline 3 & 5 & 4 & 4 & 5 & 5 & 5 & 3 & 3 & 3 & 4 & 3 \\
\hline 4 & 3 & 3 & 2 & 3 & 5 & 5 & 3 & 5 & 3 & 4 & 3 \\
\hline 5 & 2 & 3 & 2 & 2 & 4 & 4 & 4 & 4 & 5 & 5 & 5 \\
\hline
\end{tabular}
alternatif dengan urutan terbaik pada perangkingan $\mathrm{Q}$ sedangkan $\mathrm{DQ}$, dimana $\mathrm{m}$ merupakan jumlah alternatif.

\section{Hasil dan Pembahasan}

Dari hasil wawancara di PT. Telkomsel khususnya Indihome, dalam menentukan kriteria disini peneliti melakukan kuisioner terhadap 10 salesman yang perlu di uji validitasnya dengan. Berikut hasil dari uji validitas kuisioner.

Tabel 1. Uji Validitas terhadap Kuisioner 


\begin{tabular}{|c|c|c|c|c|c|c|c|c|c|c|c|}
\hline 6 & 4 & 4 & 4 & 4 & 5 & 4 & 5 & 4 & 4 & 5 & 4 \\
\hline 7 & 3 & 4 & 4 & 3 & 4 & 2 & 3 & 5 & 5 & 5 & 3 \\
\hline 8 & 4 & 4 & 4 & 4 & 3 & 2 & 4 & 5 & 5 & 5 & 4 \\
\hline 9 & 3 & 5 & 3 & 3 & 4 & 4 & 4 & 4 & 4 & 5 & 4 \\
\hline 10 & 4 & 5 & 4 & 4 & 3 & 4 & 3 & 5 & 4 & 3 & 4 \\
\hline $\mathrm{R}$ hitung & $\begin{array}{c}0,77 \\
8\end{array}$ & $\begin{array}{c}0,66 \\
9\end{array}$ & $\begin{array}{c}0,76 \\
7\end{array}$ & $\begin{array}{c}0,77 \\
8\end{array}$ & $\begin{array}{c}0,20 \\
8\end{array}$ & $\begin{array}{c}0,03 \\
8\end{array}$ & $\begin{array}{c}0,15 \\
4\end{array}$ & $\begin{array}{c}- \\
0,201\end{array}$ & $\begin{array}{c}- \\
0,266\end{array}$ & $\begin{array}{c}- \\
0,18 \\
9\end{array}$ & $\begin{array}{c}- \\
0,29 \\
0\end{array}$ \\
\hline R table & $\begin{array}{c}0.63 \\
2 \\
\end{array}$ & $\begin{array}{c}0.63 \\
2 \\
\end{array}$ & $\begin{array}{c}0.63 \\
2 \\
\end{array}$ & $\begin{array}{c}0.63 \\
2 \\
\end{array}$ & $\begin{array}{c}0.63 \\
2 \\
\end{array}$ & $\begin{array}{c}0.63 \\
2 \\
\end{array}$ & $\begin{array}{c}0.63 \\
2 \\
\end{array}$ & 0.632 & 0.632 & $\begin{array}{c}0.63 \\
2 \\
\end{array}$ & $\begin{array}{c}0.63 \\
2 \\
\end{array}$ \\
\hline Keterangan & $\begin{array}{c}\text { Vali } \\
\mathrm{d}\end{array}$ & $\begin{array}{c}\text { Vali } \\
\mathrm{d}\end{array}$ & $\begin{array}{c}\text { Vali } \\
\text { d }\end{array}$ & $\begin{array}{c}\text { Vali } \\
\mathrm{d}\end{array}$ & $\begin{array}{c}\text { Tida } \\
\mathrm{k}\end{array}$ & $\begin{array}{c}\text { Tida } \\
\mathrm{k}\end{array}$ & $\begin{array}{c}\text { Tida } \\
\mathrm{k}\end{array}$ & $\begin{array}{c}\text { Tida } \\
\mathrm{k}\end{array}$ & $\begin{array}{c}\text { Tida } \\
\mathrm{k}\end{array}$ & $\begin{array}{c}\text { Tida } \\
\mathrm{k}\end{array}$ & $\begin{array}{c}\text { Tida } \\
\mathrm{k}\end{array}$ \\
\hline
\end{tabular}

Keterangan K1 = Absen, K2 = Pencapaian Target, K3 = Kerja Sama Tim, K4 = Perilaku

Setelah didapatkan kriteria yang valid, maka peneliti mencocokan data alternative dan kriteria. Data alternatif dan kriteria dapat dilihat pada table 2 di bawah ini :

Tabel 2. Data Alternatif dan Kriteria

\begin{tabular}{|c|c|c|c|c|}
\hline \multirow{2}{*}{ Alternatif } & \multicolumn{4}{|c|}{ Kriteria } \\
\cline { 2 - 5 } & Absen & Pencapaian Target & Kerja Sama Tim & Perilaku \\
\hline Mirza & 4 hari & 10 Pelanggan & Bagus & Sangat Bagus \\
\hline Saris & 6 hari & 8 Pelanggan & Sangat Bagus & Kurang Bagus \\
\hline Rahmad & 2 hari & 12 Pelanggan & Kurang Bagus & Bagus \\
\hline Rudi Harta & 5 hari & 5 Pelanggan & Bagus & Bagus \\
\hline Sugiono & 10 hari & 25 Pelanggan & Sangat Bagus & Tidak Bagus \\
\hline Robie & 12 hari & 20 Pelanggan & Sangat Bagus & Bagus \\
\hline Arleno & 1 hari & 10 Pelanggan & Bagus & Sangat Bagus \\
\hline
\end{tabular}

Metode Vikor memerlukan nilai bobot kriteria untuk dijadikan proses perhitungan, bobot kriteria sebagai berikut :

Tabel 3. Bobot Kriteria Absen

\begin{tabular}{|c|c|}
\hline Kriteria Absen & Bobot \\
\hline $1-4$ hari & 4 \\
\hline 5-7 hari & 3 \\
\hline 8-10 hari & 2 \\
\hline 11-20 hari & 1 \\
\hline
\end{tabular}

Tabel 4. Bobot Kriteria Pencapaian Target

\begin{tabular}{|c|c|}
\hline Kriteria Pencapaian Target & Bobot \\
\hline 5-9 Pelanggan & 1 \\
\hline 10-15 Pelanggan & 2 \\
\hline 16-20 Pelanggan & 3 \\
\hline 21-30 Pelanggan & 4 \\
\hline
\end{tabular}

Tabel 5. Bobot Kriteria Kerja Sama Tim

\begin{tabular}{|c|c|}
\hline Kriteria Kerja Sama Tim & Bobot \\
\hline Tidak Bagus & 1 \\
\hline Kurang Bagus & 2 \\
\hline Bagus & 3 \\
\hline Sangat Bagus & 4 \\
\hline
\end{tabular}


Tabel 6. Bobot Kriteria Perilaku

\begin{tabular}{|c|c|}
\hline Kriteria Perilaku & Bobot \\
\hline Tidak Bagus & 1 \\
\hline Kurang Bagus & 2 \\
\hline Bagus & 3 \\
\hline Sangat Bagus & 4 \\
\hline
\end{tabular}

Setelah nilai kriteria sudah didapatkan selanjutnya penulis melakukan rating kecocokan dari setiap alternatif pada kriteria, rating kecocokan dapat di lihat pada tabel di bawah ini:

Tabel 7. Rating Kecocokan Setiap Alternatif pada Kriteria

\begin{tabular}{|c|c|c|c|c|}
\hline \multirow{2}{*}{ Alternatif } & \multicolumn{5}{|c|}{ Kriteria } \\
\cline { 2 - 5 } & Absen & Pencapaian Target & Kerja Sama Tim & Perilaku \\
\hline Mirza & 4 & 2 & 3 & 4 \\
\hline Saris & 3 & 1 & 4 & 2 \\
\hline Rahmad & 4 & 2 & 2 & 3 \\
\hline Rudi Harta & 3 & 1 & 3 & 3 \\
\hline Sugiono & 2 & 4 & 4 & 3 \\
\hline Robie & 1 & 3 & 4 & 4 \\
\hline Arleno & 4 & 2 & 3 & 1 \\
\hline
\end{tabular}

Setelah rating kecocokan didapatkan, langkah selanjutnya melakukan perhitungan metode Vikor, dengan tahap-tahap pengerjaannya.

1. Membuat matrik keputusan alternatif dan kriteria (F) dengan persamaan (1).

$$
F=\left[\begin{array}{llll}
4 & 2 & 3 & 4 \\
3 & 1 & 4 & 2 \\
4 & 2 & 2 & 3 \\
3 & 1 & 3 & 3 \\
2 & 4 & 4 & 1 \\
1 & 3 & 4 & 3 \\
4 & 2 & 3 & 4
\end{array}\right]
$$

2. Menentukan bobot untuk setiap kriteria (W) dengan persamaan (2).

Tabel 8. Bobot Kriteria

\begin{tabular}{|l|c|}
\hline \multicolumn{1}{|c|}{ Kriteria } & Bobot \\
\hline Absen & 0.20 \\
\hline Pencapaian Target & 0.40 \\
\hline Kerja Sama Tim & 0.30 \\
\hline Perlikau & 0.10 \\
\hline Total Bobot & 1 \\
\hline
\end{tabular}

3. Membuat matrik normalisasi $(\mathrm{N})$ dengan menentukan nilai maximum dan minimum untuk mendapatkan solusi ideal dari setiap kriteria.

a. Nilai Maximum dan Minimum Kriteria Absen

$f_{\text {absen }}^{+}=\max \left\{f_{\text {absen, } 1} ; f_{\text {absen, }, 2} ; f_{\text {absen, } 3 ;} ; f_{\text {absen }, 4} ; f_{\text {absen, } 5} ; f_{\text {absen, } 6} ; f_{\text {absen }, 7}\right\}$

$f^{+}$absen $=\max \{4 ; 3 ; 4 ; 3 ; 2 ; 1 ; 4\}$

$f^{+}$absen $=4$

$f_{\text {absen }}=\min \left\{f_{\text {absen }, 1} ; f_{\text {absen, } 2} ; f_{\text {absen }, 3} ; f_{\text {absen, } 4} ; f_{\text {absen, } 5} ; f_{\text {absen }, 6} ; f_{\text {absen }, 7}\right\}$

$f_{\text {absen }}=\min \{4 ; 3 ; 4 ; 3 ; 2 ; 1 ; 4\}$

$f_{\text {absen }}=1$

b. Nilai Maximum dan Minimum Kriteria Pencapaian Target

$f_{\text {pencapaian target }}^{+}=\max \left\{f_{\text {pencapaian target, } 1} ; f_{\text {pencapaian target, } 2} ; f_{\text {pencapaian target, } 3 ;} f_{\text {pencapaian target }, 4} ; f_{\text {pencapaian target }, 5}\right.$ $\left.f_{\text {pencapaian target, } 6} ; f_{\text {pencapaian target, } 7}\right\}$ 
$f^{+}$pencapaian target $=\max \{2 ; 1 ; 2 ; 1 ; 4 ; 3 ; 2\}$

$f^{+}$pencapaian target $=4$

$f_{\text {pencapaian target }}=\min \left\{f_{\text {pencapaian target, } 1} ; f_{\text {pencapaian target }, 2} ; f_{\text {pencapaian target }, 3 ;} ; f_{\text {pencapaian target, } 4} ; f_{\text {pencapaian target }, 5}\right.$; $\left.f_{\text {pencapaian target, } 6} ; f_{\text {pencapaian target, } 7}\right\}$

$f_{\text {pencapaian target }}=\min \{2 ; 1 ; 2 ; 1 ; 4 ; 3 ; 2\}$

$f_{\text {pencapaian target }}=1$

c. Nilai Maximum dan Minimum Kriteria Kerja Sama Tim

$f^{+}{ }_{\text {kerja sama tim }}=\max \left\{f_{\text {kerja sama tim, }, 1} ; f_{\text {kerja sama tim, }, 2} ; ; f_{\text {kerja sama tim, }, 3} ; f_{\text {kerja sama tim, }, 4} ; ; f_{\text {kerja sama tim }, 5} ; ; f_{\text {kerja }}\right.$ sama tim, $\left.6 ; f_{\text {kerja sama tim }, 7\}}\right\}$

$f^{+}$kerja sama tim $=\max \{3 ; 4 ; 2 ; 3 ; 4 ; 4 ; 3\}$

$f^{+}$kerja sama tim $=4$

$f_{\text {kerja sama tim }}=\min \left\{f_{\text {kerja sama tim, }, 1} ; f_{\text {kerja sama tim }, 2} ; ; f_{\text {kerja sama tim }, 3} ; f_{\text {kerja sama tim }, 4} ; ; f_{\text {kerja sama tim }, 5} ; ; f_{\text {kerja }}\right.$ sama tim,6; $\left.; f_{\text {kerja sama tim, } 7\}}\right\}$

$f_{\text {kerja sama tim }}=\min \{3 ; 4 ; 2 ; 3 ; 4 ; 4 ; 3\}$

$f_{\text {kerja sama tim }}=2$

d. Nilai Maximum dan Minimum Kriteria Perilaku

$f_{\text {perilaku }}^{+}=\max \left\{f_{\text {perilaku, } 1} ; f_{\text {perilaku, } 2} ; f_{\text {perilaku, }, 3 ;} f_{\text {perilaku, } 4} ; f_{\text {perilaku, }, 5} ; f_{\text {perilaku, } 6} ; f_{\text {perilaku, }, 7}\right\}$

$f^{+}$perilaku $=\max \{4 ; 2 ; 3 ; 3 ; 1 ; 3 ; 4\}$

$f^{+}$perilaku $=4$

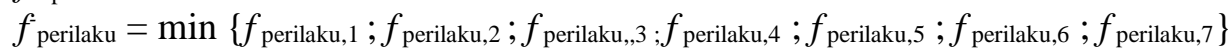

$f_{\text {perilaku }}=\min \{4 ; 2 ; 3 ; 3 ; 1 ; 3 ; 4\}$

$f_{\text {perilaku }}=1$

Nilai maximum dan minumum semua kriteria dapat dilihat pada tabel di bawah ini :

Tabel 9. Nilai Maximum dan Minimum Kriteria

\begin{tabular}{|l|c|c|}
\hline \multicolumn{1}{|c|}{ Kriteria } & Nilai Max & Nilai Minimum \\
\hline Absen & 4 & 2 \\
\hline Pencapaian Target & 4 & 2 \\
\hline Kerja Sama Tim & 4 & 1 \\
\hline Perlikau & 4 & 2 \\
\hline
\end{tabular}

Setelah nilai maximum dan minimum didapatkan maka selajutnya menghitung normalisasi matrik keputusan $(\mathrm{N})$ dengan persamaan (3).

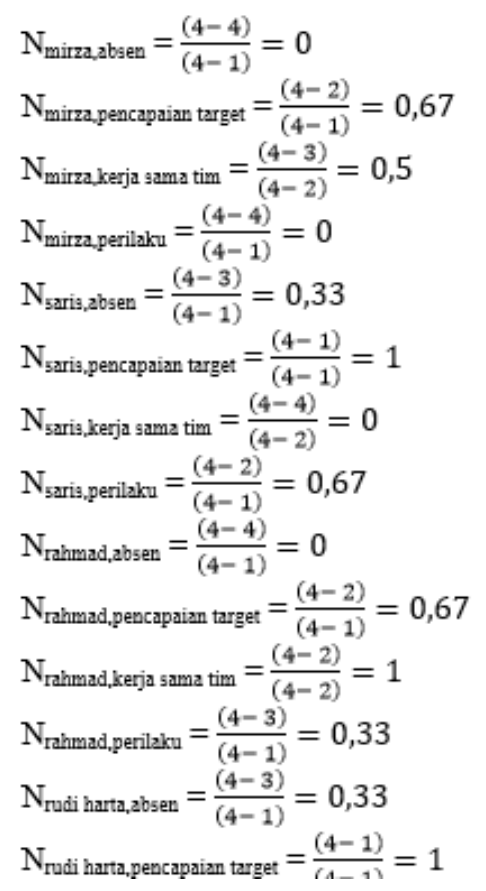

$$
\begin{aligned}
& \mathrm{N}_{\text {rudi harta,kerja sama tim }}=\frac{(4-3)}{(4-2)}=0,5 \\
& \mathrm{~N}_{\text {rudi harta,periliku }}=\frac{(4-3)}{(4-1)}=0,33 \\
& \mathrm{~N}_{\text {sugiono,absen }}=\frac{(4-2)}{(4-1)}=0,67 \\
& \mathrm{~N}_{\text {sugiono,pencapain target }}=\frac{(4-4)}{(4-1)}=0 \\
& \mathrm{~N}_{\text {sugiono,kerja sama tim }}=\frac{(4-4)}{(4-2)}=0 \\
& \mathrm{~N}_{\text {suggiono }, \text { perilaku }}=\frac{(4-1)}{(4-1)}=1 \\
& \mathrm{~N}_{\text {robie,absen }}=\frac{(4-1)}{(4-1)}=1 \\
& \mathrm{~N}_{\text {robie,pencapaian target }}=\frac{(4-3)}{(4-1)}=0,67 \\
& \mathrm{~N}_{\text {robie,kerja sama tim }}=\frac{(4-4)}{(4-2)}=0 \\
& \mathrm{~N}_{\text {robie,perilaku }}=\frac{(4-3)}{(4-1)}=0,67 \\
& \mathrm{~N}_{\text {arleno,absen }}=\frac{(4-4)}{(4-1)}=0 \\
& \mathrm{~N}_{\text {arleno, pencapaian target }}=\frac{(4-2)}{(4-1)}=0,67 \\
& \mathrm{~N}_{\text {arleno,kerja sama tim }}=\frac{(4-3)}{(4-2)}=0,5 \\
& \mathrm{~N}_{\text {arleno,perilaku }}=\frac{(4-4)}{(A-1)}=0
\end{aligned}
$$


Dari perhitungan diatas, maka diperoleh matrik normalisasi sebagai berikut :

$$
\mathrm{N}=\left[\begin{array}{cccc}
0 & 0,67 & 0,5 & 0 \\
0,33 & 1 & 0 & 0,67 \\
0 & 0,67 & 1 & 0,33 \\
0,33 & 1 & 0,5 & 0,33 \\
0,67 & 0 & 0 & 1 \\
1 & 0,67 & 0 & 0,67 \\
0 & 0,67 & 0,5 & 0
\end{array}\right]
$$

4. Menghitung matrik normalisasi Bobot $\left(\mathrm{F}^{*}\right)$

Normalisasi bobot ini dilakukan dengan cara melakukan perkalian bobot kriteria (W) dengan nilai data yang sudah di normalisasi $(\mathrm{N})$, persamaannya (4)

a. Kriteria Absen

$$
\begin{array}{ll}
\text { Mirza } & =0 \times 0,20 \\
& =0 \\
\text { Saris } & =0,33 \times 0,20 \\
\text { Rahmad } & =0,066 \\
& =0 \times 0,20 \\
\text { Rudi Harta } & =0,33 \times 0,20 \\
\text { Sugiono } & =0,066 \\
\text { Robie } & =0,67 \times 0,20 \\
\text { Arleno } & =1 \times 0,20 \\
& =0,2 \\
& =0 \times 0,20 \\
& =0
\end{array}
$$

b. Kriteria Pencapaian Target

Mirza $=0,67 \times 0,40$

$\begin{array}{ll} & =0,268 \\ \text { Saris } & =1 \times 0,40\end{array}$

$\begin{aligned} & =0,4 \\ \text { Rahmad } & =0,67 \times 0,40\end{aligned}$

$$
=0,268
$$

Rudi Harta $=1 \times 0,40$

$$
=0,4
$$

Sugiono $=0 \times 0,40$

$\begin{array}{ll} & =0 \\ \text { Robie } & =0,67 \times 0,40\end{array}$

$$
\begin{array}{ll} 
& =0,268 \\
\text { Arleno } & =0,67 \times 0,40 \\
& =0,268
\end{array}
$$

d. Kriteria Perilaku

$\begin{array}{ll}\text { Mirza } & =0 \times 0,10 \\ & =0 \\ \text { Saris } & =0,67 \times 0,10 \\ \text { Rahmad } & =0,067 \\ \text { Rudi Harta } & =0,33 \times 0,10 \\ \text { Sugiono } & =0,033 \times 0,10 \\ \text { Robie } & =0 \times 0,10 \\ \text { Arleno } & =0,67 \times 0,10 \\ & =0,067 \\ & =0 \times 0,10 \\ & =0\end{array}$

c. Kriteria Kerja Sama Tim

Setelah normalisasi bobot $\mathrm{F}^{*}$ di dapatkan, maka hasilnya dapat di lihat dibawah ini :

$$
\mathrm{F} *=\left[\begin{array}{cccc}
0 & 0,268 & 0,15 & 0 \\
0,066 & 0,4 & 0 & 0,067 \\
0 & 0,268 & 0,3 & 0,033 \\
0,066 & 0,4 & 0,15 & 0,033 \\
0,134 & 0 & 0 & 0,1 \\
0,2 & 0,268 & 0 & 0,067 \\
0 & 0,268 & 0,15 & 0
\end{array}\right]
$$


5. Menghitung utility measure (S) dan regret measure (R) dari setiap alternatif, dengan persamaan (5) dan (6)

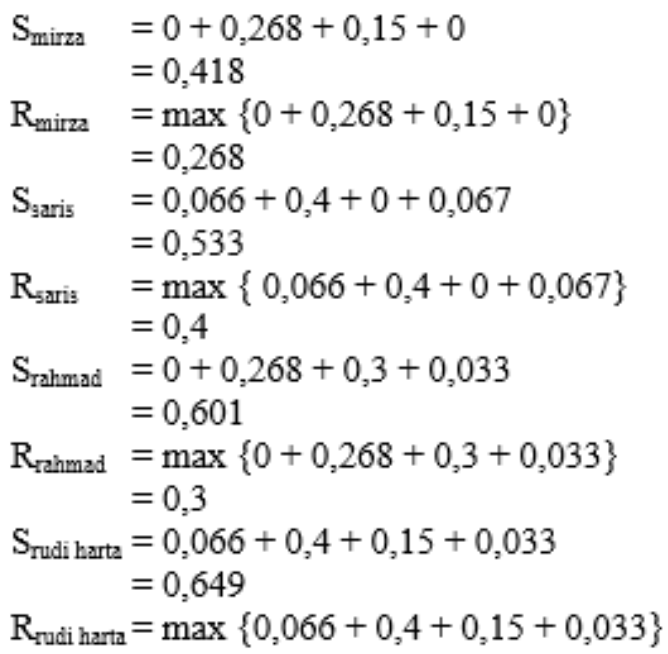

$$
\begin{aligned}
& =0,4 \\
\mathrm{~S}_{\text {sugiono }} & =0,134+0+0+0,1 \\
& =0,234 \\
\mathrm{R}_{\text {sugiono }} & =\max \{0,134+0+0+0,1\} \\
& =0,1 \\
\mathrm{~S}_{\text {robie }} & =0,2+0,268+0+0,067 \\
& =0,535 \\
\mathrm{R}_{\text {robie }} & =\max \{0,2+0,268+0+0,067\} \\
& =0,268 \\
\mathrm{~S}_{\text {urleno }} & =0+0,268+0,15+0 \\
& =0,418 \\
\mathrm{R}_{\text {urleno }} & =\max \{0+0,268+0,15+0\} \\
& =0,268
\end{aligned}
$$

Dari hasil perhitungan S dan R di atas, dapat dilihat pada tabel di bawah ini :

Tabel 10 Perhitungan nilai S dan R

\begin{tabular}{|c|c|c|}
\hline Alternatif / Salesman & Nilai S & Nilai R \\
\hline Mirza & 0,418 & 0,268 \\
\hline Saris & 0,533 & 0,4 \\
\hline Rahmad & 0,601 & 0,3 \\
\hline Rudi Harta & 0,649 & 0,4 \\
\hline Sugiono & 0,234 & 0,1 \\
\hline Robie & 0,535 & 0,268 \\
\hline Arleno & 0,418 & 0,268 \\
\hline
\end{tabular}

Setelah hasil perhitungan $\mathrm{S}$ dan $\mathrm{R}$ didapatkan, maka langkah selanjutnya melakukan perhitungan $\mathrm{S}^{+}, \mathrm{S}^{-}, \mathrm{R}^{+}, \mathrm{R}^{-}$dari nilai $\mathrm{S}$ dan $\mathrm{R}$. Hasil nya di bawah ini :

$$
\begin{aligned}
\mathrm{S}^{+} & =\max \{0,418 ; 0,533 ; 0,601 ; 0,649 ; 0,234 ; 0,535 ; 0,418\} \\
& =0,649 \\
\mathrm{~S}^{-} & =\min \{0,418 ; 0,533 ; 0,601 ; 0,649 ; 0,234 ; 0,535 ; 0,418\} \\
& =0,234 \\
\mathrm{R}^{+} & =\max \{0,268 ; 0,4 ; 0,3 ; 0,4 ; 0,1 ; 0,268 ; 0,268\} \\
& =0,4 \\
\mathrm{R}^{-} & =\min \{0,268 ; 0,4 ; 0,3 ; 0,4 ; 0,1 ; 0,268 ; 0,268\} \\
& =0,1
\end{aligned}
$$

6. Menghitung Indeks VIKOR dengan persamaan (7)

$$
\begin{aligned}
\mathrm{Q}_{\text {mirza }} & =0,5[(0,418-0,234) /(0,649-0,234)]+(1-0,5)[(0,268-0,1) /(0,4-0,1)] \\
& =0,5 \\
\mathrm{Q}_{\text {saris }} & =0,5[(0,533-0,234) /(0,649-0,234)]+(1-0,5)[(0,4-0,1) /(0,4-0,1)] \\
& =0,86 \\
\mathrm{Q}_{\text {rahmad }} & =0,5[(0,601-0,234) /(0,649-0,234)]+(1-0,5)[(0,3-0,1) /(0,4-0,1)] \\
& =0,77 \\
Q_{\text {rudiharta }} & =0,5[(0,649-0,234) /(0,649-0,234)]+(1-0,5)[(0,4-0,1) /(0,4-0,1)] \\
& =1 \\
Q_{\text {sugiono }} & =0,5[(0,234-0,234) /(0,649-0,234)]+(1-0,5)[(0,1-0,1) /(0,4-0,1)] \\
& =0 \\
Q_{\text {robie }} & =0,5[(0,535-0,234) /(0,649-0,234)]+(1-0,5)[(0,268-0,1) /(0,4-0,1)] \\
& =0,64
\end{aligned}
$$


$\begin{aligned} Q_{\text {arleno }} & =0,5[(0,418-0,234) /(0,649-0,234)]+(1-0,5)[(0,268-0,1) /(0,4-0,1)] \\ & =0,5\end{aligned}$

Hasil dari indeks vikor merupakan hasil perangkingan. Perangkingan bisa di lihat pada tabel di bawah ini :

Tabel 11 Hasil Perangkingan

\begin{tabular}{|c|c|c|}
\hline Alternatif / Salesman & Qi & Rangking \\
\hline Mirza & 0,5 & 2 \\
\hline Saris & 0,86 & 5 \\
\hline Rahmad & 0,77 & 4 \\
\hline Rudi Harta & 1 & 6 \\
\hline Sugiono & 0 & 1 \\
\hline Robie & 0,64 & 3 \\
\hline Arleno & 0,5 & 2 \\
\hline
\end{tabular}

7. Melakukan solusi kompromi dua solusi, jika kondisi acceptable advantage dengan persamaan

(8) dan (9).

$$
\begin{aligned}
\mathrm{DQ} & =\frac{1}{(7-1)} \\
& =0,167 \\
\mathrm{Q}\left(\mathrm{A}_{2}\right)-\mathrm{Q}\left(\mathrm{A}_{2}\right) & =0,5-0 \\
& =0,5
\end{aligned}
$$

Nilai yang dihasilkan adalah 0,5 sedangkan hasil DQ 0,167 maka kondisi tersebut merupakan kondisi Acceptable advantage karena nilai yang dihasilkan lebih besar dari nilai DQ.

\section{Kesimpulan}

Berdasarkan hasil perhitungan sistem pendukung keputusan menggunakan metode Vikor, maka peneliti menarik kesimpulan sebagai berikut :

1) Metode Vikor mendapatkan hasil perangkingan bahwa salesman Sugiono merupakan hasil perangkingan yang pertama.

2) Dalam menghitung nilai $S$ dan $R$ sangat berpengaruh terhadap hasil akhir yaitu perangkingan.

3) Mampu menghasilkan nilai normalisasi setiap kriteria

\section{Daftar Pustaka}

[1] D. Nababan et al., "Sistem Pendukung Keputusan Reward Bonus Karyawan Dengan Metode Topsis," vol. 3, no. 6, hal. 2-6, 1970.

[2] H. Tumanggor, M. Haloho, P. Ramadhani, dan S. D. Nasution, "Penerapan Metode VIKOR Dalam Penentuan Penerima Dana Bantuan Rumah Tidak Layak Huni," vol. 5, no. 1, hal. 71-78, 2018.

[3] I. K. P. S. Gede Suwardika, "Penerapan Metode VIKOR pada Pengambilan Keputusan Seleksi Calon Penerima Beasiswa Bidikmisi Universitas Terbuka," vol. 2, no. 1, hal. 2435, 2018.

[4] E. C. Pramulanto, M. Imrona, E. Darwiyanto, F. Informatika, dan U. Telkom, "Aplikasi Pendukung Keputusan untuk Pemilihan Produk Asuransi dengan Metode Entropy dan Vikor pada AJB Bumiputera 1912 Jepara," vol. 2, no. 1, hal. 1283-1294, 2015.

[5] N. Azizah dan S. Winiarti, "Sistem Pendukung Keputusan Seleksi Calon Karyawan Dengan Metode Promethee Studi Kasus Pamella Group Yogyakarta," J. Sarj. Tek. Inform., vol. 2, hal. 1061-1075, 2014.

[6] Sugiono, Metode Penelitian Kuantitatif, Kualitatif dan R\&D. Bandung, 2011.

[7] A. Y. Saputra, "Sistem Pendukung Keputusan Penentuan Nomor Urut Caleg dengan Metode SAW," Citec J., vol. 2, no. 2, hal. 93-101, 2015. 
[8] R. Yanto, "Sistem Pendukung Keputusan Prioritas Investasi dalam upaya Peningkatan Kualitas Perguruan Tinggi," J. RESTI (Rekayasa Sist. dan Teknol. Informasi), vol. 1, no. 3, hal. 211-216, 2017.

[9] Y. Primadasa dan V. Amalia, "Penerapan Metode Multi Factor Evaluation Process untuk Pemilihan Tanaman Pangan di Kabupaten Musi Rawas," J. Sisfo, vol. 07, no. 01, hal. 47-58, 2017.

[10] P. Studi, T. Informatika, F. Teknologi, U. Bunda, dan M. Jakarta, "Sistem Pendukung Keputusan Untuk Penjurusan Mahasiswa ( Studi Kasus : Teknik Informatika Universitas Bunda Mulia )," vol. 2015, no. Sentika, hal. 109-120, 2015.

[11] M. W. P. Agatmadja dan A. Suri, "Penerapan Metode VIKOR Dalam Pemilihan Calon Peserta Olimpiade Olahraga Siswa Nasional ( O2SN )," vol. 5, no. 2, hal. 91-96, 2018.

[12] N. I. Widiastuti, "Rancangan Dasar: VIKOR untuk Peringkasan Otomatis Preliminary Design : VIKOR for Automatic Summarization," no. 112, 2015.

\section{(i) (2)}

BY DA Digital Zone: Jurnal teknologi informasi dan Komunikasi is licensed under a Creative Commons Attribution International (CC BY-SA 4.0) 